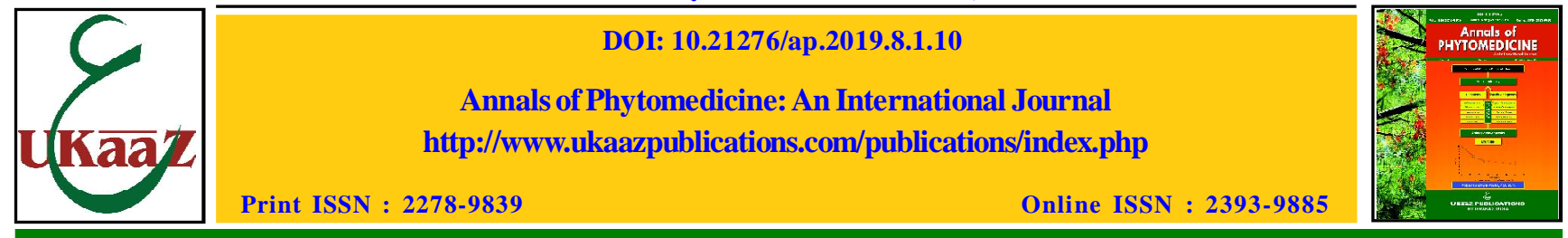

Original article

\title{
Evaluation of antipyretic, muscle relaxant and neurobehavioural activities of various leaf extracts of Citrullus colocynthis Schrad.
}

\author{
Rashmi Sagar and V.K. Dumka \\ Department of Veterinary Pharmacology and Toxicology, College of Veterinary Sciences, Guru Angad Dev Veterinary \\ and Animal Sciences University, Ludhiana-141004, Punjab, India
}

Received January 4, 2019: Revised February 25, 2019: Accepted February 28, 2019: Published online June 30, 2019

\begin{abstract}
Different leaf extracts of Citrullus colocynthis Schrad., i.e., alcoholic, acetone and chloroform were investigated for antipyretic activity, muscle relaxant activity and neurobehavioural activity at the dose rate of $50 \mathrm{mg} / \mathrm{kg}$ and $100 \mathrm{mg} / \mathrm{kg}$ in wistar rats. Antipyretic activity was evaluated using E. coli lipopolysacharide $(2 \mu \mathrm{g} / \mathrm{kg})$. For muscle relaxant activity, rota-rod apparatus was used and fall-off time was noted. For the assessment of neurobehavioural profile, elevated plus maze was used and anxiolytic responses produced by the extracts were noted. Rodents (rats and mice) have an aversion for open spaces and prefer enclosed ones, therefore spend more time in enclosed spaces (thigmotaxis). Time spent in open and closed arms was automatically recorded by the camera attached to the computer through software. In evaluation of antipyretic activity, alcoholic extract @ $100 \mathrm{mg} / \mathrm{kg}$ showed maximum response when compared to control as temperature started to decrease after $2 \mathrm{~h}$ of drug administration and came to normal after $5 \mathrm{~h}$. However, present study revealed no muscle relaxant and neurobehavioural activity of different leaf extracts of $C$. colocynthis as none of the extracts showed any significant change in the evaluation parameteres when compared to the control group.
\end{abstract}

Keywords: Citrullus colocynthis Schrad., antipyretic, muscle relaxant, neurobehavioural, elevated plus maze

\section{Introduction}

Recently, there has been a change in universal thinking from allopathy to alternative system of medicine which can be pronounced as 'back to nature' approach. Environment has bestowed our country with abundant prosperity of therapeutic vegetation, due to which India has been referred to as the 'medicinal garden' of the humanity since many ages. Moreover, ancient civilizations such as South America, China, India, Egypt, etc., are still using numerous plant therapies. Even today, plants remain a primary source of healthcare for majority of the population in the world. More than $80 \%$ population in the rural areas of the world is dependent on plant based traditional medicines including traditional systems of medicine such as Ayurveda, Unani and traditional Chinese medicine (Majeed, 2017). These concepts forced the scientists to discover modern medicines where plants are used as the source due to presence of active chemical constituents (Dang, 2018). India is one of the 12 mega biodiversity centers, having 45,000 plant species; its diversity is unmatched due to the 15 different agroclimatic zones, 10 vegetative zones, and 15 biotic provinces (Nayanabhirama, 2016; Biradar, 2015; Yunus, 2015).

Ethnomedicinal studies play a major role to highlight the endemic plant species, notably for the invention of recent crude medicine.

\footnotetext{
Author for correspondence: Dr. Rashmi Sagar

Department of Pharmacology and Toxicology, College of Veterinary Sciences, Guru Angad Dev Veterinary and Animal Sciences University, Ludhiana 141004, India.

E-mail: rashmi.sagar58@gmail.com

Tel.: +91-8284010900
}

Copyright () 2019 Ukaaz Publications. All rights reserved.

Email: ukaaz@yahoo.com; Website: www.ukaazpublications.com
Documentation of native medicinal information of ancient plant species has resulted in development of variety of recent medicine. Medicinal plants are found through varied habitats and landscapes. The most accustomed herbal medicines used by many tribes in our country are plants belonging to Fabaceae, Euphorbiaceae, Asteraceae, Apiaceae, Cucurbitaceae, Acanthaceae, Papaveraceae, Capparidaceae and Solanaceae families. Traditional medicine is an important source of potentially useful new compounds for the development of chemotherapeutic agents. Ethnopharmacologists, botanists, microbiologists and natural-products chemists have been exploring the earth for phytochemicals and 'leads' which could be developed for treatment of infectious diseases. Generally, natural drug substances often perform vital and appreciable roles in the modern system of medicine, thereby justifying their presence in the prevailing therapeutic arsenal. These serve as extremely useful natural drugs, provide basic compounds which prove to be less toxic and more effective drug molecule (Kan, 2006). There are thousands of plants used in traditional medicine by different cultural groups throughout the world. A large number of these traditional medicinal plants remain to be studied (Subramoniam, 2014).

Citrullus colocynthis Schrad. (Family: Cucurbitaceae) is a perennial herb, usually trailing and commonly found wild in the sandy lands of North West Punjab, Sind, and Central and southern India, and coromandal coast and also found indigenous in Arabia, West Asia, and Tropical Africa and in the Mediterranean region. Chemical constituents of plants are of utmost importance for the discovery of therapeutic agents and in establishing the medicinal value of traditional plants. This plant is annual (in wild), herbaceous, bearing monoecious type flowers, pepo fruit and numerous seeds. Its fruits 
are used as robust laxative. This plant produces fruits known as colocynth apples that are the same as the common Citrullus vulgaris and tastes bitter. It possesses solitary sterile flowers and an oversized, fleshy perennial root, that rises to from slender, tough, angular, vine-like stems and branched tendrils. The fruits are bitter, pungent and used as purgative, anthelmintic, antipyretic, carminative and also used for treatment of tumors, ascites, leucoderma, ulcers, asthma, bronchitis, jaundice, enlargement of spleen, dyspepsia, constipation, anaemia, throat diseases, elephantiasis and joint pain. Roots are useful in jaundice, ascites, urinary diseases, rheumatism and given in abdominal enlargements and in cough and asthmatic attacks of children (Nadkarni, 2007). Fruit is also useful against fever, intestinal parasites, hepatic and abdominal diseases, visceral and cerebral congestions. Root extract is used against jaundice, urinary diseases, rheumatism, etc., and seeds are diuretic (Vohora and Khan, 1981). The leaf of the plant is melancholic purgative and used for melancholia and epilepsy (Tonkaboni, 2007; Heravi, 1992). Many pharmacological activities have been recorded in fruits, fruit pulp and seeds of the plant but there is paucity of data regarding the pharmacological activities in leaves of the plant. So, in the light of above, the present study investigated the potential of different leaf extracts of $C$. colocynthis as an antipyretic, muscle relaxant and neurobehavioural agent in rodents.

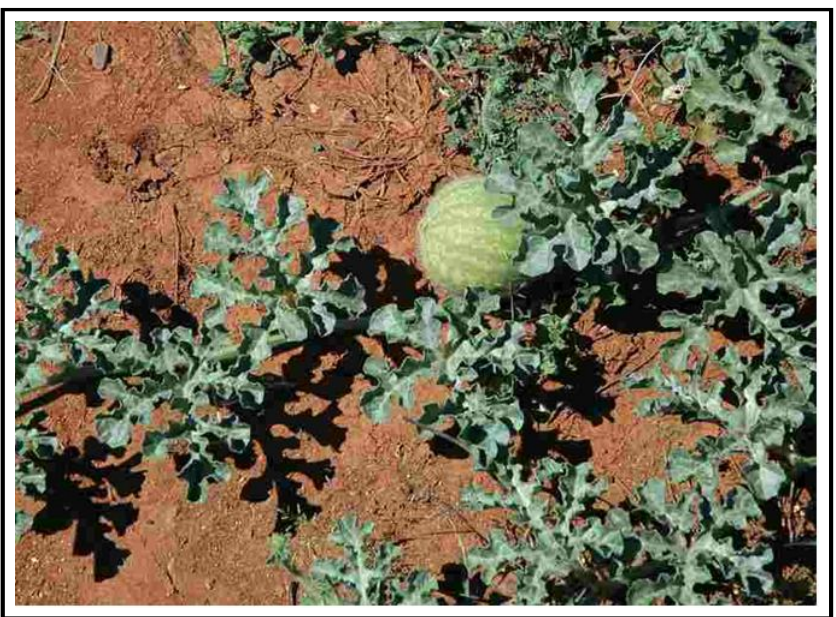

Figure 1: Citrullus colocynthis Schrad. leaves and fruit.

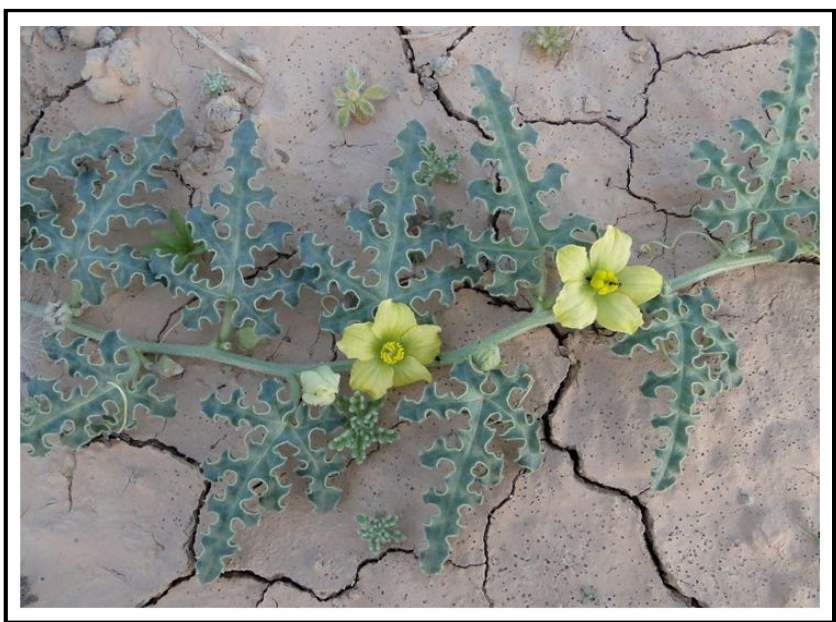

Figure 2: Citrullus colocynthis Schrad. flowers.

\section{Materials and Methods}

\subsection{Plant material}

Based on ethnopharmacological information, leaves were collected from campus of Guru Angad Dev Veterinary and Animal Sciences University, Ludhiana, Punjab, India and were authenticated by the botanist of Collaborative Ayurveda Research Centre, GADVASU, Ludhiana. Immediately after collection, leaves were washed and dried under sunlight. The dried leaves were finely grounded into powder, weighed and kept for further analysis.

\subsection{Extraction}

Different type of extracts of the plant were prepared using various menstruum, viz., ethanol, acetone and chloroform by maceration technique.

\subsection{Ethanolic extract}

100 gram of powdered leaves was soaked in 1 litre absolute alcohol at room temperature for $72 \mathrm{~h}$ and stirred at frequent time intervals. After maceration, the extract was initially filtered using muslin cloth and then re-filtered again using Whatman filter paper No 1. The filtrate obtained was evaporated at room temperature. The residue $\left(3.8 \mathrm{~g}\right.$ ) obtained was lyophilized and kept at $4{ }^{\circ} \mathrm{C}$ in air tight bottles until use.

\subsection{Acetone extract}

100 gram of powdered leaves was soaked in 1 litre acetone at room temperature for $72 \mathrm{~h}$. and stirred at frequent time intervals. After maceration, the extract was initially filtered using muslin cloth and then re-filtered again using Whatman filter paper No 1 . The filtrate obtained was evaporated at room temperature. The residue $(3 \mathrm{~g})$ obtained was lyophilized and kept at $4^{\circ} \mathrm{C}$ in air tight bottles until use.

\subsection{Chloroform extract}

100 gram of powdered leaves was soaked in 1 litre chloroform at room temperature for $48 \mathrm{~h}$ and stirred at frequent time intervals. After maceration, the extract was initially filtered using muslin cloth and re-filtered again using Whatman filter paper No 1 . The filtrate obtained was evaporated at room temperature. The residue $(2.8 \mathrm{~g})$ obtained was lyophilized and kept at $4^{\circ} \mathrm{C}$ until use.

\subsection{Drugs and chemicals}

Paracetamol, E.coli endotoxin, carboxymethyl cellulose sodium and diazepam were used in experiments.

\subsection{Animals}

The present investigation was conducted on 50 rats, aged 3-4 months, weighing 180-200 gram, at Guru Angad Dev Veterinary and Animal Sciences University, Ludhiana, Punjab, India. The animals were purchased from small animal colony, GADVASU. The animals were acclimatized to the environment for ten days before starting experiment and kept in cages under standard laboratory conditions of temperature $\left(27-30^{\circ} \mathrm{C}\right)$, with a $12 \mathrm{~h}$ light cycle. All animals were fed commercial rat pellets procured from Ashirwad Industries, Mohali (Punjab). Feed and water were provided ad libitum to the animals. The experimental protocol was approved 
by the Institutional Animal Ethics Committee (IAEC) vide reference No. VMC/13/1786-1806, dated 4/4/13 and was conducted in accordance with ethical committee guidelines. Animals were divided into ten groups of five animals each. Group I served as control, group II as positive control and remaining groups served as test groups. Groups III and IV were administrated with alcoholic extract of concentration $50 \mathrm{mg} / \mathrm{kg}$ and $100 \mathrm{mg} / \mathrm{kg}$ orally, respectively. Groups V and VI were administered with acetone extract at concentration of $50 \mathrm{mg} / \mathrm{kg}$ and $100 \mathrm{mg} / \mathrm{kg}$, respectively. Similarly, groups VII and VIII were administered with chloroform extract having concentrations of $50 \mathrm{mg} / \mathrm{kg}$ and $100 \mathrm{mg} / \mathrm{kg}$, respectively.

\subsection{Antipyretic activity}

Fifty rats were divided into 10 groups of five animals each. Initially, normal body temperature of the animals was noted down. All animals were administered with $E$. coli endotoxin @ $2 \mu \mathrm{g} / \mathrm{kg}$ i.p. to induce fever. Group I served as control without any treatment. Group II was administered paracetamol orally @ $50 \mathrm{mg} / \mathrm{kg}$ as a standard drug to serve as positive control. Groups III and IV were administrated alcoholic leaf extract of plant @ $50 \mathrm{mg} / \mathrm{kg}$ and 100 $\mathrm{mg} / \mathrm{kg}$ orally, respectively. Groups V and VI were administered with acetone extract @ $50 \mathrm{mg} / \mathrm{kg}$ and $100 \mathrm{mg} / \mathrm{kg}$, respectively. Similarly, group VII and VIII were administered with chloroform extract @ $50 \mathrm{mg} / \mathrm{kg}$ and $100 \mathrm{mg} / \mathrm{kg}$ orally. Fever was recorded at duration of $1 \mathrm{~h}, 2 \mathrm{~h}, 3 \mathrm{~h}, 4 \mathrm{~h}, 5 \mathrm{~h}$ and $6 \mathrm{~h}$ with the help of thermometer.

\subsection{Muscle relaxant activity}

In the present study, the animals were trained to maintain balance for 40-60 sec on the rota-rod rotating at a speed of $25 \mathrm{rpm}$. Only those rats which could balance themselves for 45-60 sec were selected for study. Each rat was placed individually on the rotarod, and time spent on rota-rod was noted. The control group was treated with distilled water. In the positive control group, diazepam @ $10 \mathrm{mg} / \mathrm{kg}$ was administered orally as a standard drug. In group III, group V, group VII, the alcoholic, acetone and chloroform extracts were given, respectively, @ $50 \mathrm{mg} / \mathrm{kg}$ orally whereas in group IV, group VI, group VIII, respectively. These extracts were given @ $100 \mathrm{mg} / \mathrm{kg}$ orally. Fall off time was noted at $0 \mathrm{~h}, 1 \mathrm{~h}$ and $2 \mathrm{~h}$, respectively.

\subsection{Neurobehavioural activity}

Elevated plus maze is the most simple apparatus to study neuroprotective effects (Sunanda et al., 2014) and anxiolytic responses produced by the test drugs. Rodents (rats and mice) have an aversion for open spaces and prefer enclosed ones, therefore spend more time in enclosed spaces (thigmotaxis). When animals enter open arm, they freeze, become immobile, defecate and show anxious behavior (Pellow et al., 1985).

For the study, animals were divided into five groups of five animals each. Control group was given DW. Group II was given alcoholic extract @ $100 \mathrm{mg} / \mathrm{kg}$ orally. Group III was given acetone extract @ $100 \mathrm{mg} / \mathrm{kg}$ orally. Group IV was given chloroform extract @ 100 $\mathrm{mg} / \mathrm{kg}$ orally. Time spent in open and closed arms was automatically recorded by the camera attached to the computer through software.

\subsection{Stastical analysis}

The results obtained were analysed statistically by one-way ANOVA using SPSS Software at 5\% level of significance. Differences with $p<0.05$ were considered statistically significant.

\section{Results}

\subsection{Antipyretic activity}

The results of the antipyretic activity of various extracts of C. colocynthis in wistar rats are shown in the Table 1 and Figure 3. E. coli endotoxin was administered i.p. @ $2 \mu \mathrm{g} / \mathrm{kg}$ to induce fever in all the groups.

\subsection{Muscle relaxant activity}

The results depicting the muscle relaxant activity of various leaf extracts of $C$. colocynthis on wistar rats are given in the Table 2 and Figure 4. Group I served as control and group II served as standard. In the standard group, diazepam @ $4 \mathrm{mg} / \mathrm{kg}$ was administered orally,

\subsection{Neurobehavioural activity}

The results demonstrating the effect of various extracts of C. colocynthis on neurobehavioral activity of wistar rats are given in the Tables 3 and 4.

Table 1: Effect of different leaf extracts of $C$. colocynthis on E. coli endotoxin $(2 \mu \mathrm{g} / \mathrm{kg})$ induced fever in rats

\begin{tabular}{|l|c|c|c|c|c|c|c|}
\hline \multicolumn{7}{|c|}{ Increase in temperature $\left({ }^{\circ} \mathbf{C}\right)$ in comparison to normal $(\mathbf{0}$ h) value } \\
\hline Group & Dose $(\mathbf{m g} / \mathbf{k g})$ & $\mathbf{1} \mathrm{h}$ & $\mathbf{2} \mathrm{h}$ & $\mathbf{3} \mathrm{h}$ & $\mathbf{4} \mathrm{h}$ & $\mathbf{5} \mathrm{h}$ & $\mathbf{6} \mathrm{h}$ \\
\hline Alcoholic & 50 & $1.16 \pm 0.04^{\mathrm{ab}}$ & $1.48 \pm 0.08^{\mathrm{bc}}$ & $1.48 \pm 0.08^{\mathrm{b}}$ & $1.08 \pm 0.07^{\mathrm{c}}$ & $0.48 \pm 0.058^{\mathrm{c}}$ & $0.28 \pm 0.05^{\mathrm{bc}}$ \\
Alcoholic & 100 & $1.04 \pm 0.12^{\mathrm{bc}}$ & $1.08 \pm 0.10^{\mathrm{e}}$ & $0.52 \pm 0.08^{\mathrm{e}}$ & $0.24 \pm 0.07^{\mathrm{f}}$ & $0.00 \pm 0.0^{\mathrm{d}}$ & $0.00 \pm 0.0^{\mathrm{d}}$ \\
Acetone & 50 & $1.16 \pm 0.04^{\mathrm{ab}}$ & $1.36 \pm 0.04^{\mathrm{cd}}$ & $1.24 \pm 0.04^{\mathrm{c}}$ & $0.84 \pm 0.07^{\mathrm{d}}$ & $0.52 \pm 0.05^{\mathrm{c}}$ & $0.24 \pm 0.04^{\mathrm{c}}$ \\
Acetone & 100 & $1.16 \pm 0.07^{\mathrm{ab}}$ & $1.16 \pm 0.07^{\mathrm{de}}$ & $0.80 \pm 0.06^{\mathrm{d}}$ & $0.56 \pm 0.04^{\mathrm{e}}$ & $0.32 \pm 0.05^{\mathrm{c}}$ & $0.16 \pm 0.08^{\mathrm{cd}}$ \\
Chloroform & 50 & $1.36 \pm 0.04^{\mathrm{a}}$ & $1.60 \pm 0.06^{\mathrm{ab}}$ & $1.60 \pm 0.06^{\mathrm{b}}$ & $1.56 \pm 0.04^{\mathrm{b}}$ & $1.08 \pm 0.08^{\mathrm{b}}$ & $0.48 \pm 0.05^{\mathrm{b}}$ \\
Chloroform & 100 & $1.16 \pm 0.047^{\mathrm{ab}}$ & $1.44 \pm 0.04^{\mathrm{bc}}$ & $0.96 \pm 0.04^{\mathrm{d}}$ & $0.64 \pm 0.07^{\mathrm{de}}$ & $0.36 \pm 0.04^{\mathrm{c}}$ & $0.16 \pm 0.07^{\mathrm{cd}}$ \\
Standard & 50 & $0.84 \pm 0.04^{\mathrm{c}}$ & $0.44 \pm 0.04^{\mathrm{f}}$ & $0.04 \pm 0.03^{\mathrm{f}}$ & $0.00 \pm 0.0^{\mathrm{g}}$ & $0.00 \pm 0.0^{\mathrm{d}}$ & $0.00 \pm 0.0^{\mathrm{d}}$ \\
Control & -- & $0.92 \pm 0.10^{\mathrm{c}}$ & $1.72 \pm 0.10^{\mathrm{a}}$ & $2.48 \pm 0.12^{\mathrm{a}}$ & $2.48 \pm 0.12^{\mathrm{a}}$ & $2.16 \pm 0.18^{\mathrm{a}}$ & $1.84 \pm 0.15^{\mathrm{a}}$ \\
\hline
\end{tabular}

Values lacking a common superscript in given column differ significantly from each other $(p<0.05)$. 


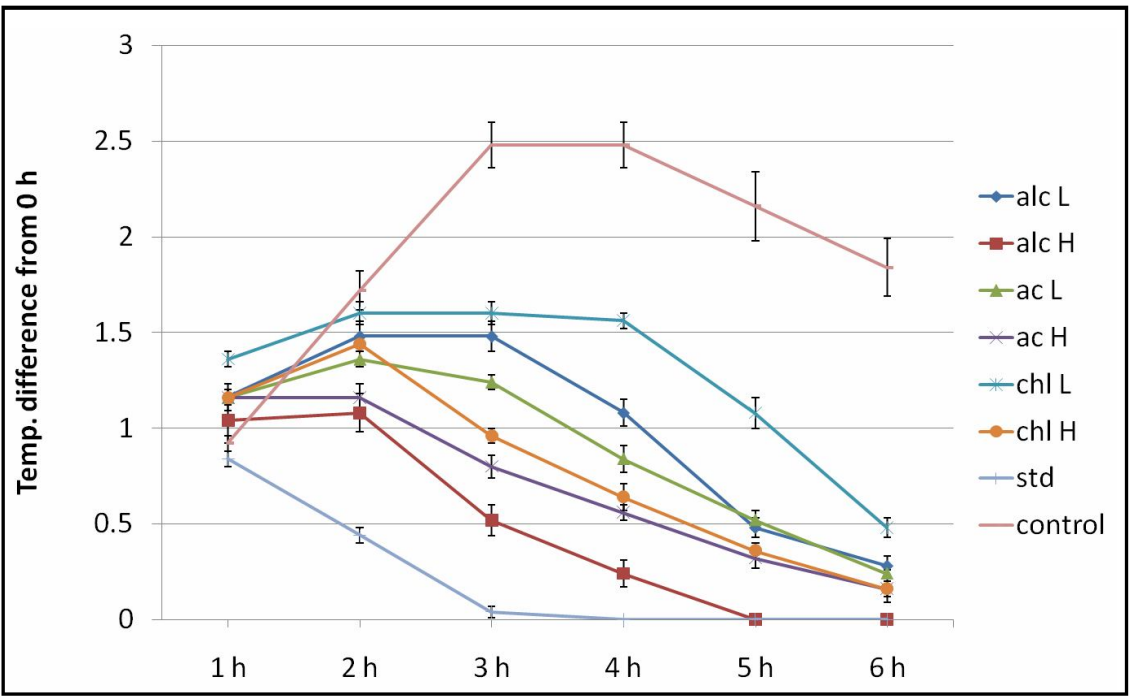

Figure 3: Graph showing temperature difference (in ${ }^{\circ} \mathrm{C}$ ) from control group in extracts administered groups of animals under study.

Table 2: Effect of different leaf extracts of $C$. colocynthis on muscle relaxant activity in rats fall off time ( $\mathrm{sec})$

\begin{tabular}{|l|c|c|c|c|}
\hline Extract & Dose $(\mathbf{m g} / \mathbf{k g})$ & $\mathbf{0 ~ h}$ & $\mathbf{1} \mathbf{h}$ & $\mathbf{2} \mathbf{~ h}$ \\
\hline Alcoholic & 50 & $46.2 \pm 0.73^{\mathrm{a}}$ & $47.8 \pm 0.49^{\mathrm{a}}$ & $46.8 \pm 0.73^{\mathrm{a}}$ \\
Alcoholic & 100 & $47.2 \pm 1.04^{\mathrm{a}}$ & $47.8 \pm 0.91^{\mathrm{a}}$ & $47.4 \pm 0.87^{\mathrm{a}}$ \\
Acetone & 50 & $47.0 \pm 1.22^{\mathrm{a}}$ & $47.2 \pm 0.58^{\mathrm{a}}$ & $47.0 \pm 0.94^{\mathrm{a}}$ \\
Acetone & 100 & $46.8 \pm 0.79^{\mathrm{a}}$ & $48.0 \pm 1.09^{\mathrm{a}}$ & $46.4 \pm 1.43^{\mathrm{a}}$ \\
Chloroform & 50 & $47.4 \pm 0.81^{\mathrm{a}}$ & $47.4 \pm 0.87^{\mathrm{a}}$ & $46.8 \pm 1.15^{\mathrm{a}}$ \\
Chloroform & 100 & $46.6 \pm 1.82^{\mathrm{a}}$ & $47.2 \pm 1.46^{\mathrm{a}}$ & $46.2 \pm 1.15^{\mathrm{a}}$ \\
Standard & 2 & $47.2 \pm 0.58^{\mathrm{a}}$ & $6.2 \pm 0.58^{\mathrm{b}}$ & $05.8 \pm 0.37^{\mathrm{b}}$ \\
Control & - & $47.6 \pm 0.92^{\mathrm{a}}$ & $46.6 \pm 1.02^{\mathrm{a}}$ & $46.6 \pm 1.24^{\mathrm{a}}$ \\
\hline
\end{tabular}

Values lacking a common superscript in given column differ significantly from each other $(p<0.05)$.

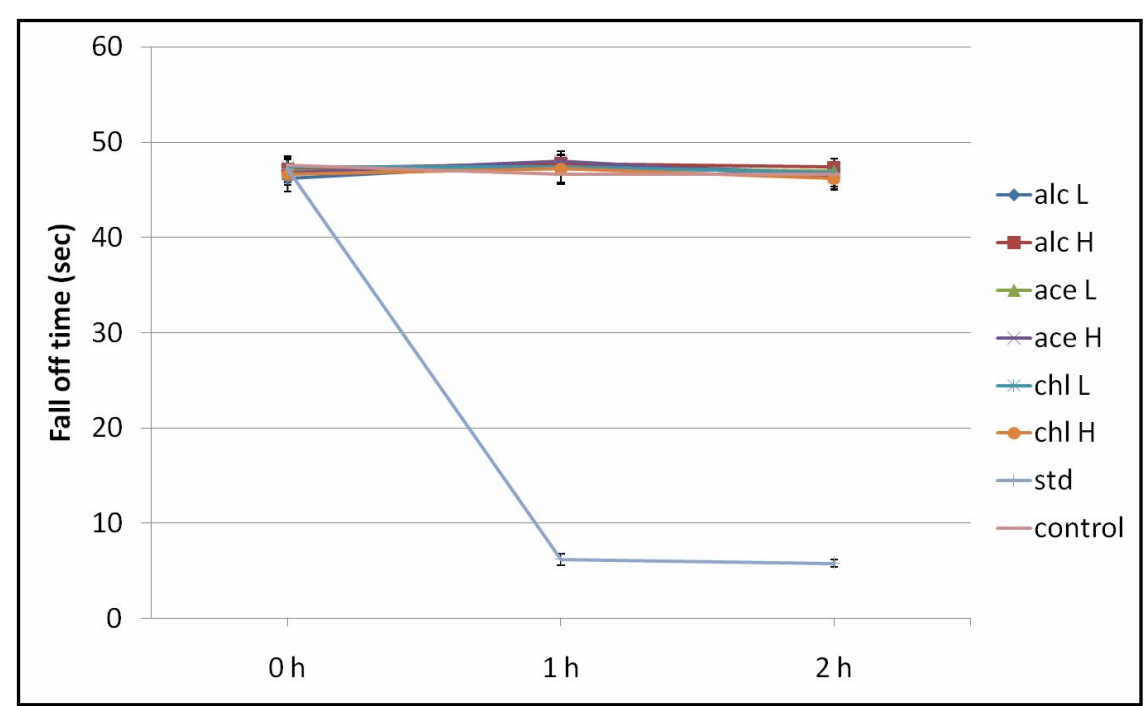

Figure 4: The figure shows the fall of time versus the time-interval after the drug administration. 
Table 3: Effect of different leaf extracts of C. colocynthis (10\%) on neurobehavioural activity of rats

\begin{tabular}{|l|c|c|}
\hline Extracts & $\begin{array}{c}\text { Time spent in } \\
\text { open arms(s) }\end{array}$ & $\begin{array}{c}\text { Time spent in } \\
\text { closed arms(s) }\end{array}$ \\
\hline Control & $6.56 \pm 0.5^{\mathrm{a}}$ & $880.5 \pm 3.4^{\mathrm{a}}$ \\
Alcoholic & $06.8 \pm 0.4^{\mathrm{a}}$ & $883.6 \pm 2.9^{\mathrm{a}}$ \\
Acetone & $6.98 \pm 0.4^{\mathrm{a}}$ & $883.5 \pm 4.7^{\mathrm{a}}$ \\
Chloroform & $07.1 \pm 0.4^{\mathrm{a}}$ & $884.9 \pm 3.1^{\mathrm{a}}$ \\
\hline
\end{tabular}

Values lacking a common superscript in given column differ significantly from each other $(p<0.05)$.

\section{Discussion}

\subsection{Antipyretic potential}

Fever is regulated by the immune response and inflammatory stimuli, triggering the generation of pro-pyretic messages, provoke the release of endogenous antipyretic substances. $\mathrm{PGE}_{2}$ is synthesized from arachidonic acid, which is released from cell membrane lipid by phospholipase. Arachidonic acid is metabolized by two isoforms of the COX enzyme, COX-1 and COX-2. COX-1 usually is expressed constitutively and generates prostanoids important for housekeeping functions supporting homeostasis. COX-2, on the other hand, is inducible by inflammatory signals such as the pyrogenic cytokines, IL-1b, TNF, and IL-6, as well as bacterial lipopolysaccharide. Many cells, including synoviocytes, macrophages, endothelial cells and chondrocytes have the capacity to rapidly up-regulate the expression of the COX-2 during inflammation and fever.

In the present study, group I served as control and in group II, paracetamol was used as standard drug and administered @ $50 \mathrm{mg} /$ $\mathrm{kg}$ orally. In groups III, V and VII, alcoholic, acetone and chloroform extracts were given, respectively @ $50 \mathrm{mg} / \mathrm{kg}$ orally, whereas in group IV, group VI and group VIII, these extracts were given @ 100 $\mathrm{mg} / \mathrm{kg}$ orally. In groups IV, V and VI, temperature started to decrease after $2 \mathrm{~h}$ of drug administration, whereas in group VII, temperature started to decrease after $4 \mathrm{~h}$ which is similar to the control group. In group II which was administered standard drug, the temperature started to decrease after $1 \mathrm{~h}$, achieving normalcy at $3.5 \mathrm{~h}$, whereas in groups III, V, VI, VII and VIII, temperature returned to normal range after six hours. Although, all extracts showed dose-dependent antipyretic activity but maximum activity was demonstrated by group IV in which temperature came to normal point at $5 \mathrm{~h}$. It can be proposed that the extracts act centrally like paracetamol, and reduce pyrexia by decreasing the brain concentration of prostaglandin E2 especially in the hypothalamus through its action on COX-3 or by enhancement of the production of the body's own antipyretic substances like vasopressin and arginine. Also, it is reported through preliminary photochemical screening that the plant contains alkaloids, glycosides, flavonoids and tannins which may have contributed to the antipyretic activity of the extracts as depicted in the study.

Also, in the study conducted by Reddy and Shaik (2012), maximum antipyretic activity was shown by ethanolic extract of $C$. colocynthis fruit extract against yeast-induced pyrexia model in wistar rats.

\subsection{Muscle relaxant potential}

Skeletal muscle relaxants are agents that treat both muscle spasm and spasticity, acting as antispasmodic and antispasticity agents, respectively. The earliest known use of muscle relaxant drugs dates back to the $16^{\text {th }}$ century when European explorers encountered the natives of the Amazon Basin in South America who used poisontipped arrows that produced death by skeletal muscle paralysis. This poison known today as curare, led to some of the earliest scientific studies in pharmacology. Its active ingredient, tubocurarine, an alkaloid as well as many synthetic derivatives, played a significant role in scientific experiments to determine the function of acetylcholine in neuromuscular transmission.

In the present study, group I served as control and group II served as standard. In the standard group, diazepam @ $4 \mathrm{mg} / \mathrm{kg}$ was administered orally. In group III, group V and group VII, the alcoholic, acetone and chloroform extracts were given, respectively @ $50 \mathrm{mg}$ / $\mathrm{kg}$, whereas in group IV, group VI and group VIII, these extracts were given @ $100 \mathrm{mg} / \mathrm{kg}$ orally. Rats were placed on rota-rod and fall-off time was noted. In standard group, there was significant decrease in fall-off time after $1 \mathrm{~h}$ and remained upto $2 \mathrm{~h}$ after drug administration. In the control group, there was no significant decrease in fall-off time. All other groups showed non-significant decrease in fall-off time. Hence, present study showed no muscle relaxant activity of $C$. colocynthis leaf extracts.

In contrast to the present study, Tirumalasetti et al. (2015) reported skeletal muscle relaxant activity of aqueous extract of Nerium oleander flowers in albino rats. Also, Aparna et al. (2015) reported significant muscle relaxant activity of aqueous leaf extract of Carica papaya.

\subsection{Neurobehavioral profile}

The elevated plus maze has been described as a simple method for assessing anxiety responses of rodents by Pellow et al. (1985). Unlike other behavioural assays used to assess anxiety responses which depend on the presentation of noxious stimuli that typically produce a conditioned response, the elevated plus maze relies upon rats' proclivity toward enclosed spaces (approach) and an unconditioned fear of heights/open spaces (avoidance), also known as thigmotaxis.

In the present study, group I served as control. group II was given alcoholic extract @ $100 \mathrm{mg} / \mathrm{kg}$ orally and group III was given acetone extract @ $100 \mathrm{mg} / \mathrm{kg}$ orally. Similarly, group IV was given chloroform extract @ $100 \mathrm{mg} / \mathrm{kg}$ orally. Time spent in open and closed arms was recorded automatically with the help of inbuilt overhead camera and software. It was observed that in all the extract groups, there was no significant change in the time spent in open or closed arms as compared to control group which revealed that none of the extracts modify the normal thigmotaxic behavior of rodents. In contrary to present study, Latha et al. (2015) reported significant neurobehavioural activity of aqeuous extract of Coriandrum sativum.

\section{Conclusion}

The present study was undertaken to study the antipyretic, muscle relaxant and anxiolytic potential of leaf extracts of $C$. colocynthis. Three different extracts, i.e., alcoholic, acetone and chloroform were prepared using standard procedure. In this study, all extracts showed dose dependent antipyretic activity but maximum activity was 
seen in the alcoholic extract of C. colocynthis @ $100 \mathrm{mg} / \mathrm{kg}$. However, the study also revealed absence of muscle relaxant activity of different leaf extracts of $C$. colocynthis. Also, no significant change was observed in the neurobehavioral profile of the animals when compared to the control group revealing that none of the extract administered groups showed any significant change in the normal thigmotactic behaviour of the animals under study.

\section{Conflict of interest}

The authors declare that no conflict of interest exists in the course of conducting this research. Both the authors had final decision regarding the manuscript and the decision to submit the findings for publication.

\section{References}

Aparna, S.; Gopalakrishna, C.; Gopi, M.; Ashok Kumar, D.; Fathima, S. K. and Sudhakarbabu, A.M.S. ( 2015). Skeletal muscle relaxant activity of aqueous extract of Carica papaya leaves on wistar rats. Journal de Afrikana, 2:44-52.

Biradar, D.P. (2015). Medicinal plants and phytomedicines. Ann. Phytomed., 4(1):1-5.

Dang, R. (2018). Role of antinutrient metabolites of plant on production of secondary metabolites and human health. Ann. Phytomed., 7(1):1-4.

Heravi, M. (1992). Alabnya an al-Haghayegh al-Advia. Tehran, Iran: Tehran University.

Kan, A. (2006). Pharmacognosy and Pharmabiotecnology, New Age International Ltd., New Delhi, pp:5-11.
Latha, K.; Rammohan, B.; Sunanda, B.P.V.; Maheswari, M.U. and Mohan, S.K. (2015). Evaluation of anxiolytic activity of aqueous extract of Coriandrum sativum Linn. in mice: A preliminary experimental study. Pharmacognosy Research, 7:S47-S51.

Majeed, M. (2017). Evidence-based medicinal plant products for the health care of world population. Ann. Phytomed., 6(1):1-4.

Nadkarni, K. M. (2007). Indian Materia Medica, Bombay Popular Prakashan, Bombay. 3rd Edn., pp:335-337.

Nayanabhirama, U. (2016). Status on herbal drugs and their future perspectives. Ann. Phytomed., 5(1):1-3.

Pellow, S.; Chopin, P.; File, S. E. and Briley, M. (1985). Validation of open, closed arm entries in an elevated plus maze as a measure of anxiety in the rat. Journal of Neuroscience Methods, 14:149-67.

Reddy, V. P. and Shaik, A. ( 2012). Evaluation of antipyretic activity of Citrullus colocynthis fruit extract against yeast induced Pyrexia model in wistar rats. Journal of Pharmacy Research, 5:4.

Subramoniam, A. (2014). Phytomedicines for healthcare. Ann Phytomed., 3:1-3.

Tirumalasetti, J.; Patel, M.; Shaikh, U.; Harini, K. and Shankar, J. (2015). Evaluation of skeletal muscle relaxant activity of aqueous extract of Nerium oleander flowers in albino rats. Indian Journal of Pharmacology, 47(4):409.

Tonkaboni, M. M. (2007). Tohfeh al-momenin. Tehran: Shahid Beheshti University of Medical Sciences.

Vohora, S.B. and Khan, M.S.Y. (1981). Diuretic studies on plant principles of Indian drugs. Pharmaceutical Industry, 161:39-40.

Yunus, M. ( 2015). Herbal medicine in India. Ann. Phytomed., 4:1-3.

Citation: Rashmi Sagar and Dumka, V.K. (2019). Evaluation of antipyretic, muscle relaxant and neurobehavioural activities of various leaf extracts of Citrullus colocynthis Schrad. Ann. Phytomed., 8(1):88-93. 